\title{
THE LAW OF PROPAGATION IN HADITH PERSPECTIVE
}

\author{
Hilman Mauludin \\ Program Studi Komunikasi Penyiaran Islam (KPI) \\ Fakultas Agama Islam Universitas Islam Nusantara (UNINUS) Bandung \\ Email: hilmanmauludin@uninus.ac.id \\ Ifah Khadijah \\ Program Studi Pendidikan Guru Madrasah Ibtidaiyah (PGMI) \\ FAI Universitas Islam Nusantara Bandung \\ Email: ifahkhadijah@uninus.ac.id
}

\begin{abstract}
This article tries to discuss about law of propagation in hadith perspective. By Using library research, this article found that for every Muslim, da'wah is an obligation that cannot be negotiable. The obligation of da'wah is something that is impossible to avoid from his life, because it is very attached to self-recognition as adherents of Islam. Indirectly, every Muslim as the bearer of missionary mission. Based on the results of the analysis, especially the study of the hadith and according to most scholars in general the da'wah law is farḍ kifāyah, meaning that if it has been done by a group of people, the burden of that obligation falls from the others.
\end{abstract}

Keywords: propagation; preaching; farọ kifāyah

\section{A. INTRODUCTION}

Islam as a religion of da'wah (Poston, 1992), which commands its people to convey the teachings of Islam to all humans (Habibi \& Habibi, 2016)and can provide enlightenment, as rahmatan lil 'alamin. The teachings of Islam promise to the welfare of life in the world and the hereafter, as long as the people remain strict in carrying out his teachings. Submission and dissemination of Islamic teachings through da'wah with various strategies (Bryant \& Ali, 1998).

Da'wah in the context of the development and dissemination of Islamic teachings becomes a fundamental aspect of activity (Račius, 2007). It is impossible for Islam to be known and followed so that it has as many followers today without the process of preaching the Prophet. Da'wah activities in its development are traditionalized by scholars from one generation to the next (Shah, 2013). They are better known as da'i or Islamic mujahid who are predicated as warathat al-anbiya '. (Sabibi, 2008, p. 20) 
Al-Qur'an and Hadith become the main doctrines that cannot be separated (Weiss, 2002) in an effort to inculcate cultural values. But for further implementation of the strategies, methods and tips or movements carried out for cultural propaganda are more referring to the traditions that position as bayān (explanatory) to the verses of the Qur'an which are still mujmal (global), 'àm (general) and muțlaq (without restrictions). Even the hadith independently can function as muqarrir (settler) of a law that has not been established by the Qur'an, (Husain Munawwar, 2011, p. 24) because the contents of the Qur'an are universal in nature which requires further detailed explanation of the hadith (Alwazna, 2016).

Speaking of da'wah issues, basically it is the responsibility of every Muslim, by not looking at the class and social status possessed by each individual (Wahid, 2019). Da'wah itself is not limited by time and space. Preaching does not have to wait for someone to be able to memorize the verses of preaching, the method of preaching or to become an ustadz first when every Muslim sees munkar, then it is his duty to remind him. Based on this, in the end it is very important to conduct a discussion related to the Analysis of Da'wah Law in the alHadith Perspective.

\section{B. METHOD}

This article was written using literature study. A number of sources that have been traced successfully, are compiled and then recomposed to form a complete concept construction. The prepositional narrative is re-explained and used to form a new explanation of the law of da'wah. The results are presented in a separate conclusion which states that the law of da'wah is fardu kifayah.

\section{RESULT AND DISCUSSION}

\section{Da'wah: Islamic Law Perspective}

The law of da'wah consists of two words namely law and da'wah. According to M.H. Tirtaatmadja law is all the rules (norms) that must be obeyed in the behavior of actions in the association of life with the threat of having to compensate if breaking those rules will endanger oneself or property. Whereas J.C.T. Simorangkir and Woerjono Sastropranoto are of the opinion that laws are coercive regulations that determine human behavior in a society created by official bodies, which violations of those regulations result in action being taken, that is, with certain laws. (Hasanuddin, 1996, p. 12)

Based on the division of law in Islam, it can be concluded that the da'wah law is a compulsory law, which is an obligation that must be carried out by every Muslim community in accordance with their capabilities and capacities. This author's conclusion is based on several considerations:

a. The verse clause that states about the obligation of da'wah is to use fi amar which means it is mandatory to do.

b. Da'wah activity is an activity which in principle conveys truth and goodness and therefore communicates kindness and truth that is the duty of all Muslims in accordance with their respective abilities. 
c. There is an opinion which states that the obligation of da'wah is fardu kifayah, as long as the author's observations have dwarfed the meaning of da'wah, into something that is permitted and not to be done. This is very contrary to the purpose and principle of preaching that is conveying the truth.

d. To restore the function of da'wah and uphold the truth on earth, the duty of da'wah must be included in the fard 'ain law, which is an obligation that must be done by every Muslim who has baliqh.

Based on the verses of the Koran, scholars agree that the da'wah law in general is mandatory, while the debate is whether the obligation is charged to individual Muslims or only charged to groups of people from the whole, differences of opinion regarding the proselytizing law due to different ways their understanding of the proofs of nakli despite the reality of the conditions of every Muslim with different knowledge and abilities. The verse that becomes the main point of opinion is the letter Ali-Imran verse 104. It means: "And let there be among you a group of people who call for virtue, order to the ma'ruf and prevent from evil. they are the lucky ones. "

In this paragraph there are three obligations faced. The two are centered on the one. One is inviting goodness. And raises two tasks. The first is to make ma'ruf (Hasjmy, 1984, p. 302) and the second to prohibit evil. (Hasjmy, 1984, p. 302) The good two verbs sent by Allah to humans are to make ma'ruf and prevent the evil (Hamka, 2015, p. 31). In the interpretation of Jamaluddin al-Qasimi stated in Surah Al-Imran verse 104 gives reasons about the obligation to call on the people and prevent them from breaking, and oblige you as stipulated in the Qur'an and Sunnah (Jamaluddin, 2003, p. 44).

In the interpretation of al-amidi this verse is the argument that shows that telling the good and forbidding evil is obligatory (Husain bin Basyir bin Yahya al Amidi, n.d., p. 63). Then in the interpretation of the Ahkam this verse implies that the first obligatory law is ordered to the good, second Fardhu kifayah (Imam Abi Bakri Ahmad Arrazi Al-Jhasas, 2001, p. 44) means not mandatory for each person if he did it.

Ahmad Mustafa Al-Maraghi - in interpreting Ali Imran's letter: 104 - distinguishes between الخير is something which contains goodness for mankind in matters of religion (religious principles) and worldly. The word الَْعْرُوف is what is considered good by shari'ah and reason. Here Allah Almighty, ordered to make improvements to other than them, namely members of the community and appealed to follow the orders of the shari'ah and abandon his prohibitions, as an inauguration of them to maintain shari'ah laws in order to maintain shari'a 'at and statute. So let the human soul be embedded in love for goodness and hold fast to the shari'ah (Maraghi, Sitanggal, Aly, \& Abubakar, 1987, p. 4).

According to Imam Khazin as quoted by Moh. Ali Azis states that the meaning of the meme in the letter Ali-Imran verse 104 is to function as an explanation (lil bayan) not to show the meaning of part (littab'iidh), because Allah has obliged da'wah to Muslims as His words ("You some are the best of the Ummah (Ali-Imran: 110), and therefore the proper meaning for verse 104 of the verse Ali-Imran above is that all of you should be a people who always invite to the good of governing the makruf and prevent the evil, (Aziz, 2012, p. 43) the explanation of Imam Khazin which states, that the meaning meme which has a function as an explanatory, i.e. da'wah is the duty and responsibility of every Muslim and is devoted to a 
Muslim only, but who feels that Muslims are obliged to carry out da'wah depends on their own abilities.

According to M. Quraish Sihab, the word minkum in verse 104 of the letter Ali-Imran states that there are scholars who understand in part in the sense that the preaching order ordered by that verse is not directed at everyone. For those who understand this, this verse is for those who contain two kinds of commands. The first commandment to all Muslims is to form and prepare a special group tasked with carrying out the da'wah to the good and the good and to prevent evil (Shihab, 2009, p. 73). The first command in this case could be a social institution whose job is to carry out da'wah and there are special activities by it to launch da'wah. The second commandment is that the da'wah that is launched concerns the da'wah to the kindness and blessing of the forehead mungkar. (Shihab, 2009, p. 73)

The information of min kum that causes these two obligations only position the obligatory proselytizing law only has a small scope, namely groups. If we return to the previous issue, which states that the letter mim and in the word minkum is an obligation for every Muslim who is an explanation, according to the Quraish Shihab, this is an order for Muslims to carry out the da'wah duties which are according to their abilities, indeed the intended mission is perfect preaching, then of course not everyone can carry it out. On the other hand, the needs of today's society, even such a rapid war of information with the presentation of new values are often confusing, all of them require a special group that handles da'wah and blocks misleading information, because it is more appropriate to understand the word minkum in the verse in above in the sense that some of you without demanding the obligation of each Muslim to remember each other remind, not based on the word of God in the AlAshar letter that assesses all Muslims losses, except those who believe and do good deeds, and remind each other about the truth and fortitude. (Shihab, 2009, p. 174)

From all of this information, it can be concluded that the commentators state that the word minkum is as an explanation (lil bayan) and some say that the word minkum is part (littab'iidh), but actually both can be used in the legal status of da'wah and depend on where this legal position is laid. If if lil bayan, then preaching is an obligation for every Muslim without exception in accordance with their abilities, but if you are in the position of littab'idah or part of it is there is a group tasked with carrying out the propaganda, then the two meanings between lil bayan and littab 'idah are placement Da'wah law in accordance with the ability of Muslims to uphold the truth, it could be Bayil is Muslims who have authority (power).

According to Ar-Razi, the word minkum says "one of you" actually (min) according to Dalalain is the first fact Allah Ta'ala requires all to as it says "you are part of the ummah ..." while the second is he actually does not mean responsibility answer but the obligation of both, calling "to those who are well known and prevents those who are guilty of, sometimes by hand, or verbally or by heart - then this verse is for the people who call for the good of instructing those who are ignorant of those who are ignorant (Ar-Razi, 1415, pp. 182-183).

Fuad Mohm. Facruddin and Ali al-Syamsi al Nasyar, as quoted by Salmadanis, said that implementing the amar makruj nahi mungkar is an obligation not only by certain groups, but also by all certain groups, also by all other groups of Muslims. So anyone who does not do so must straighten his way of life by committing jihad against himself which is the same nature by committing jihad against unbelievers or the wicked. The obligation of al-amr bi 
almakruf wa al-hahy an al-munkar is for every believer according to their ability, whether by lifting weapons or other means. (Salmadanis, 2000, p. 65)

It is said so strongly that the obligation of amar makruf nahi mungkar is a full responsibility for all Muslims to another Muslim, and by carrying out the activities of amar makruf nahi mungkar will cause all levels of society to be able to practice the teachings of Islam well and full of the Redha of Allah SWT, therefore, its implementation must also be in accordance with its capacity, and does not require individuals to carry out da'wah beyond their abilities.

Then the meaning of da'wah in language comes from Arabic, د و, which means that the basic tendency of something is due to sound and words (Zakariyya, 1996, p. 76, Salmadanis, 2003, p. 76). And in terms of understanding the propaganda experience development and differences in meaning in accordance with the development of science as explained above. While definitively preaching is formulated in a varied context. 3 This can be seen in the orientation and emphasis on the form of its activities including:

a. The definition of da'wah that emphasizes the process of providing motivation to carry out the message of da'wah (Islamic teachings). As stated by Ali Mahfudz that preaching is pushing people to goodness and instructions ordering actions that damage individuals and people so that they get happiness in the world and in the hereafter.

b. The definition of da'wah that emphasizes the process of spreading the da'wah message by considering methods, media and messages that are appropriate to your situation and conditions.

Da'wah can be broadly divided into two broad categories: Da'wah thoughts and Da'wah activities. The first refers to every attempt to contemplate propaganda, both ontologically, epistemologically, and axiologically. Thus, the thought of da'wah is theoretical as an effort to generalize, both through deductive and inductive thinking, in order to build the structure of da'wah science. The second category refers to every activity and missionary movement in the field. This second category is the reality of the activities of amr bi al-ma'ruf wa nahy an al-munkar in the midst of Muslims.

Basically, da'wah is the delivery of messages from the processing of thoughts of the Islamic teachings contained in the Qur'an and al-Hadith, which are then conveyed to the public or target, namely mad'u, with the aim of telling, influencing, educating, or just filling in time free. As in communication, the purpose of da'wah is nothing but to change the attitudes, traits, and behavior of the audience (al-mad'u). While the purpose of da'wah is so that mad'u is able and willing to follow the true teachings of Islam (Suhandang, 2013, p. 171).

According to H.M. Arifin., Gives the meaning of da'wah as an invitation activity in the form of oral, written, behavior and so on which is carried out consciously and planned in an effort to influence others, both individually and in groups so that arises in him an understanding, awareness and attitude of appreciation and practice the teachings of religion as a message that is conveyed to him without the elements of coercion (Arifin, 1993, p. 6). 
Based on some of the definitions stated above, it can be formulated that the meaning of da'wah is a conscious human effort in conveying the values of Islamic teachings both verbally and in writing as the realization of amar ma'ruf nahi munkar to achieve happiness in the world and the hereafter, while understanding Da'wah laws are rules that contain the obligations and the procedures for preaching in accordance with Islamic law.

\section{Purpose of Da'wah}

The purpose of da'wah is nothing but to bring society to a better and more advanced state compared to the previous situation. The main purpose of da'wah is the value or the final result to be achieved by the whole act of da'wah. To achieve this main goal, all the preparation of plans and actions must be demonstrated and directed. The main purpose of da'wah is the realization of happiness and prosperity of life in the world and in the hereafter which are blessed by Allah SWT.

According to Muriah (2000: 11-12) through da'wah is expected to be able to play a role in two directions: First, able to provide output to the community in the sense of providing a philosophical basis, direction and encouragement to form new realities better. Second, Islamic da'wah must be able to change the vision of existing social and cultural life not only seen as a tyranny, but also be used as a conducive condition for the creation of baldatun tayyibatun wa rabbun ghafur (Muariah, 2000, pp. 11-12).

\section{Da'wah Media}

Media is a tool or vehicle used to move messages from the source to the recipient. For that, media communication (mediated communication) is communication that uses channels or means to forward a message to the communicant that is far away, and / or many in number. Media communication is also called indirect communication, and as a consequence the reverse flow does not occur when communication is waged. For this reason, communication through the media is one-way so communicators do not know the communicant's response immediately. The communicator does not know the communicant's response when he communicates. Therefore, in launching media communication, the communicator must be more mature in planning and in preparation so that he feels certain that the communication will succeed. For that, he must pay attention to several factors. Communicators must know the nature of the communicant to be addressed and understand the properties of the media that will be used. The intended communication by using media can be only one person, can be with a small group of people, can also be a very large number of people (Illaihi, 2010, p. 104).

\section{Propagation Law in Hadith Perspective}

In addition to Qur'an, in the hadith there are also commands or orders to do da'wah. This preaching law also seems to be different in each person depending on the situation and conditions experienced by that person in the view of the law. Abu Sa'id Al-Khudry ra. Said, I heard the Messenger of Allah, said:

"If any of you see evil, then he should prevent it with his hands (violence or power), if he is unable to do so (because he does not have power and power), then with his tongue, and if he is unable (with his tongue) that is as weak as faith ". (HR. Muslim). (Dieb, 1998, p. 289) 
Thus according to the hadith according to the author there are two kinds of proselytizing laws namely law in general and law specifically. The law in general is that the implementation of da'wah activities is stipulated as a legal obligation fard kifayah. This is because it is not possible for all people to have potential as preachers and can carry out da'wah well. While the law in particular is the legal provisions imposed on someone who comes out of the fard kifayah law, due to one's ability and disability level.

There are three ways of preaching in the hadith. First, to prevent by hand or with the power or position of someone, who with the position or authority he has will be listened to by people or people will attack him. Second, by oral means speaking with the truth brought up to those who commit munkar and this person must have a strong mentality and in taking preventive actions. Third with the heart, this is the last way to advise others, which is the weakest condition of a person, at least he is still obliged to reject renege with his heart if he is still considered by God as someone who has faith, even though the faith is the weakest, namely mental unable to prevent munkar. Rejection of munkar with a heart is a minimum limit and a bastion where the end is from efforts to prevent munkar.

In the first way when someone has the power and ability to control others on the right path, the law is obligatory for him that is carried out in a kifayah concept to prevent munkar with his power. It also gives an understanding that it is mandatory for people who have the power to preach to prevent mingles with power or using verbal. However, if he has power but is unable to control that power, or in other words he is under someone else's control, then the law of da'wah in private and specifically becomes not obligatory for him but can change its function to become another law.

Then in the second situation where someone with his courage is able to prevent munkar by verbal means, mentally prepared to bear any risk that will occur because of his actions. Then according to the author of circumcision law fell on him to prevent munkar. That is, this can be understood that if someone who has no power but he has the mental ability to preach and he knows that the risk will occur as a result of his actions then circumcision for him to preach.

Furthermore, in the third situation where a person has no ability, and is also not mentally prepared to prevent munkar, then the law of law falls for him not to prevent munkar provided that in his soul he says that he disagrees with the renege he sees. Thus it is also understood that a person's armpits do not have power, verbal ability and do not have mental readiness then the law of immunity falls not to preach to him. Although the scholars believe that basically the da'wah law in general is fardu kifayah, however according to the writer of the da'wah law as described above it must be returned to the fardu 'ain law so that everyone acts and conveys the truth.

The above hadith is also confirmed by another hadith that Khuzaifah ra. The Prophet Said "For the sake of the substance which governs me, you must uphold to the good and you must prevent the evil deeds, or Allah will bring torment to you, then you pray to Him where Allah will not grant your request (HR. Turmudzi).

The above hadith does not explain the law of da'wah clearly, but the instructions for doing da'wah are clearly said. This also proves that according to the writers of the Da'wah law it is very closely related to the conditions and circumstances of a person. 
This hadith has been preceded by the oath of the Prophet. For Muslims who are a choice for them will get torture from God, because they have been considered by Him to have neglected this important and obligatory religious duty. So that the wrath of God is not to those who commit munkar, but to the people as a whole as His financans "And protect yourself from the torment of Allah who will not befall special people who are just wrong among you and know that God is very harsh torture (QS. AlAnfal: 25 )

\section{Conclusions}

For every Muslim, preaching is an obligation that can not be negotiable. The obligation of da'wah is something that is impossible to avoid from his life, because it is very attached to self-recognition as adherents of Islam. Indirectly, every Muslim as the bearer of missionary mission. Based on the results of the analysis above, especially the study of the hadith and according to most scholars in general the da'wah law is fardu kifayah, meaning that if it has been done by a group of people, the burden of that obligation falls from the others.

\section{BIBLIOGRAPHY}

Alwazna, R. Y. (2016). Islamic Law: Its Sources, Interpretation and the Translation of It into Laws Written in English. International Journal for the Semiotics of Law - Revue Internationale de Sémiotique Juridique, 29(2), 251-260. https://doi.org/10.1007/s11196-016-9473-x

Arifin, H. M. (1993). Psikologi Dakwah. Jakarta: Bumi Aksara.

Ar-Razi, M. (1415). Tafseer Al Fakhr Al Razi. Retrieved from http://archive.org/details/TafseerAlFakhrAIRazitafseerAlKabeerarabic

Aziz, Moh. A. (2012). Ilmu Dakwah.

Bryant, M. D., \& Ali, S. (1998). Muslim Christian Dialogue: Promise and Problems. New York: Paragon House.

Dieb, A.-B. M. (1998). Syarah Kitab Arba'in An-Nawawiyah. Jakarta.

Habibi, S. M. M., \& Habibi, S. A. (2016). Prophet Muhammad (Peace Be Upon Him) in the Bible. London: iExpertini Limited.

Hamka, P. D. (2015). Tafsir Al Azhar-Tafsir Al Quran (1st edition). Gema Insani Press.

Hasanuddin, H. (1996). Hukum Dakwah: Tinjauan Aspek Hukum dalam Berdakwah di Indonesia. Pedoman IImu Jaya.

Hasjmy, A. (1984). Dustur Dakwah Menurut Al-Qur'an. Bulan Bintang.

Husain bin Basyir bin Yahya al Amidi. (n.d.). Tafsir Al Amidi.

Husain Munawwar, S. A. (2011). Asbabul Wurud (2nd ed.). Yogyakarta: Pustaka Pelajar.

Illaihi, W. (2010). Komunikasi Dakwah. Bandung: Remaja Rosdakarya. 
Imam Abi Bakri Ahmad Arrazi Al-Jhasas. (2001). Beirut Libanon: Darul Fikri.

Jamaluddin, M. (2003). Tafsir Al-Qasimi. Darul Kutub al-Ilmiyah.

Maraghi, A. M., Sitanggal, K. A. U., Aly, H. N., \& Abubakar, B. (1987). Terjemah tafsir AlMaraghi. C.V. Toha Putra.

Muariah, S. (2000). Metodologi Dakwah Kontemporer. Yogyakarta: Mitra Pustaka.

Poston, L. (1992). Islamic Da'wah in the West: Muslim Missionary Activity and the Dynamics of Conversion to Islam. New York - Oxford: Oxford University Press.

Račius, E. (2007). Muslim Missionary Activities Between Religion and Politics: The Multiple Nature of the Islamic Da'wa. Vilniaus: Vilniaus Universitetas.

Sabibi, R. (2008). Metodologi IImu Dakwah. Yogyakarta: Pustaka Pelajar.

Salmadanis. (2000). Dakwah Dalam Perspektif Al-Qur'an dan Hadis. Jakarta: TMF.

Salmadanis. (2003). Filsafat Dakwah. Jakarta: Surau.

Shah, N. A. (2013). The Use of Force under Islamic Law. European Journal of International Law, 24(1), 343-365. https://doi.org/10.1093/ejil/cht013

Shihab, M. Q. (2009). Tafsir Al-Mishbah. Lentera Hati.

Suhandang, K. (2013). Ilmu Dakwah (Cet.1). Bandung: Rosdakarya.

Wahid, A. (2019). Gagasan Dakwah: Pendekatan Komunikasi Antar Budaya. Jakarta: Prenada Media.

Weiss, B. G. (2002). Studies in Islamic Legal Theory. Leiden: BRILL.

Zakariyya, A. I-H. A. bin F. bin. (1996). Mu'jam Maqayis al-Lughah (1st edition). Mesir: Mustafa Al Baabi. 